\title{
Interaction of Streptococcus agalactiae and cellular innate immunity in colonization and disease
}

\author{
Sybille Landwehr-Kenzel ${ }^{1,2,3} *$ and Philipp Henneke ${ }^{4,5} *$ \\ 1 Berlin-Brandenburg Center for Regenerative Therapies, Charité University Medicine Berlin, Berlin, Germany \\ ${ }_{2}^{2}$ Berlin-Brandenburg School for Regenerative Therapies, Charité University Medicine Berlin, Berlin, Germany \\ ${ }^{3}$ Department of Pediatric Pulmonology and Immunology, Charité University Medicine Berlin, Berlin, Germany \\ ${ }^{4}$ Center for Pediatrics and Adolescent Medicine, University Medical Center Freiburg, Freiburg, Germany \\ ${ }^{5}$ Center for Chronic Immunodeficiency, University Medical Center Freiburg, Freiburg, Germany
}

\section{Edited by:}

Arnaud Marchant, Université Libre de Bruxelles, Belgium

\section{Reviewed by:}

Gilles Chiocchia, Institut National de la Santé et de la Recherche Médicale,

France

Fabio Bagnoli, Novartis Vaccines, Italy

${ }^{*}$ Correspondence:

Sybille Landwehr-Kenzel, Department of Pediatric Pulmonology and

Immunology, Charité University Medicine Berlin, Augustenburger

Platz 1, Berlin 13353, Germany

e-mail: sybille.landwehr-kenzel@

charite.de:

Philipp Henneke, Center for Chronic Immunodeficiency, University

Medical Center, Breisacher Straße

117, Freiburg 79106, Germany

e-mail:philipp.henneke@

uniklinik-freiburg.de
Streptococcus agalactiae (Group B streptococcus, GBS) is highly adapted to humans, where it is a normal constituent of the intestinal and vaginal flora. Yet, GBS has highly invasive potential and causes excessive inflammation, sepsis, and death the beginning of life, in the elderly and in diabetic patients. Thus, GBS is a model pathobiont that thrives in the healthy host, but has not lost its potential virulence during coevolution with mankind. It remains incompletely understood how the innate immune system contains GBS in the natural niches, the intestinal and genital tracts, and which molecular events underlie breakdown of mucocutaneous resistance. Newborn infants between days 7 and 90 of life are at risk of a particularly striking sepsis manifestation (late-onset disease), where the transition from colonization to invasion and dissemination, and thus from health to severe sepsis is typically fulminant and not predictable. The great majority of late-onset sepsis cases are caused by one clone, GBS ST17, which expresses HvgA as a signature virulence factor and adhesin. In mice, HvgA promotes the crossing of both the mucosal and the blood-brain barrier. Expression levels of HvgA and other GBS virulence factors, such as pili and toxins, are regulated by the upstream two-component control system CovR/S. This in turn is modulated by acidic epithelial $\mathrm{pH}$, high glucose levels, and during the passage through the mouse intestine. After invasion, GBS has the ability to subvert innate immunity by mechanisms like glycerinaldehyde-3-phosphate-dehydrogenase-dependent induction of IL-10 and $\beta$-protein binding to the inhibitory phagocyte receptors sialic acid binding immunoglobulinlike lectin 5 and 14. On the host side, sensing of GBS nucleic acids and lipopeptides by both Toll-like receptors and the inflammasome appears to be critical for host resistance against GBS. Yet, comprehensive models on the interplay between GBS and human immune cells at the colonizing site are just emerging.

Keywords: S. agalactiae, cellular innate immunity, intestinal microbiota, colonization, invasion, sepsis

\section{INTRODUCTION}

Streptococcus agalactiae, Group B Streptococcus (GBS), is a commensal of the human intestinal and vaginal tract in $15-30 \%$ of healthy adults, but remains one of the most important invasive pathogens in newborn infants and the elderly (1-4). Every 10th neonate acquires GBS vertically during passage through the birth canal or shortly thereafter. In most cases, GBS can be assumed to become a normal constituent of the child's microbiome. In other cases, other colonizing bacteria that expand on the expense of GBS may replace it. These dynamic processes early in life are generally safe, as $99 \%$ of at least temporarily colonized infants will never develop invasive GBS disease (5-8). The achievement of establishing a microbiome including GBS can best be judged in light of GBS late-onset diseases (LOD) and meningitis: if GBS does not adapt, it may cause fulminant disease. Notably, crossing the intestinal barrier and the blood barrier seems to be mechanistically linked. GBS serotype III, a particularly frequent isolate in neonatal meningitis, has recently been found to exhibit specific neurotropism through expression of the adhesion factor $\operatorname{HvgA}(9,10)$. HvgA efficiently supports bacterial adhesion and transfer through to the intestinal wall and later across the blood-brain barrier, specifically the vascular endothelium and the choroid plexus (9). In other words, protection of the neonatal brain from GBS starts in the gut. Longterm neurological impairment of variable degree, which affects about $35-50 \%$ of infants surviving meningitis, has become particularly important in the Western world, where improvements in intensive care have decreased lethality of GBS invasive disease below $10 \%(9,11)$.

By definition, GBS is a normal constituent of the "intestinal microbiota," which comprises numerous bacteria, fungi, and protozoa. In a normal adult, the microbiota comprises more than 10,000 species, adding up to $1500 \mathrm{~g}$ in biomass. The composition of the microbiota is unique to the host and can be viewed as a personal fingerprint that emerges in early infancy $(12,13)$. Members of the bacterial phyla Bacteroidetes, Firmicutes (e.g., Lactobacillus and Clostridum spp), Proteobacteria, Actinobacteria (e.g., 
Bifidobacterium spp.), Fusobacteria, and Spirochaetes are the most important constituents of the gastrointestinal flora $(12,14,15)$. Notably, the microbial composition underlies temporal changes during the first year of life and differs between children born vaginally and by caesarian section (16-18). A modulating role of breast milk feeding in the composition of the neonatal microbiome, e.g., by maternal secretory IgA, antimicrobial peptides, lactoferrin, and sCD14, has been shown by several investigators (19-25). In twins, it appears that both genetic and environmental factors contribute to the composition of the intestinal microbiota $(22,26,27)$.

Colonizers of the human intestine are generally considered as "symbionts" that stabilize the intestinal homeostasis by acidification of the intraluminal milieu, maintenance of the transepithelial resistance, prevention of pathogen adherence, and continuous immune stimulation (28-32). Pathobionts are potentially pathogenic colonizers that usually reside in the intestine in coexistence with the host, but can cause severe local or systemic disease. In newborn infants, the most important examples are E. coli, enterococci, and GBS. The Janus face of GBS is underlined by the fact that $10 \%$ of all neonates are at least temporarily colonized by GBS (1-4), yet only $1 \%$ of these develops invasive disease (5-8). Beginning at birth, GBS colonization rates continuously increase to $20-30 \%$ in adults (1-4). This indicates that GBS transmission occurs not only perinatally, but also horizontally later in life. Next to the exposure to various bacterial strains, external factors like stress, drugs, diet, gastrointestinal infections, and endogenous factors, like diabetes, alter the composition of the intestinal microbiota $(21,33)$. These individual life style and health factors may explain in part, why GBS is an important cause of soft-tissue and urinary tract infections, arthritis, and sepsis in patients $>65$ years and those with chronic diseases such as stroke (OR 3.5), diabetes (OR 3.0), kidney or liver (OR 9.7) failure, and cancer (breast cancer OR 4.0) (34). In healthy adults, GBS predominantly colonizes the outer mucus layer of the colon, yet may occasionally reside in the small intestine as well (35, 36). In pregnant women, GBS is a frequent cause of urinary and upper genital tract infections, intra-amniotic infections, and sepsis $(37,38)$. Whether GBS colonization usually, i.e., in infants as well as adults, starts in the intestinal tract and expands from there to other sites, or whether GBS subsets develop at independent colonization sites of the same human influenced by the site-specific microenvironment, has not yet been clarified. Accordingly, the origin of differences in serotype distribution between non-pregnant adults with invasive disease, where serotype $\mathrm{V}$ contributes to almost 30\% of cases, and pregnant women or newborn infants, where serotypes III and Ia predominate, is not well understood $(7,39,40)$.

\section{THE PATHOGEN SITE: GBS VIRULENCE STRATEGIES TO PROGRESS FROM COLONIZATION TO DISEASE}

What can we learn from neonatal GBS sepsis models with respect to factors regulating colonization and invasion? GBS sepsis in newborn infants can be divided into early-onset disease (EOD), which occurs within the first week of life by vertical GBS transmission during delivery, and LOD, which occurs through vertical or horizontal transfer and manifests between day 7 and 3 months of age (41). However, since more than $90 \%$ of all EOD cases manifest as sepsis, pneumonia, or meningitis within the first $24-48 \mathrm{~h}$ of life, some authors limit early-onset sepsis to the first $72 \mathrm{~h}$ after birth (40,
42). Peripartum antibiotic prophylaxis has markedly decreased the incidence and case fatality rate of EOD; the incidence or clinical course of LOD, however, has remained largely unaffected. The clinical picture of LOD typically manifests as hyperinflammatory syndrome with meningitis. As outlined above, GBS serotype III is greatly overrepresented in LOD, with clonotype ST17 contributing up to $90 \%$ of all clinical isolates found in meningitis (as compared to colonizing strains). This led to the phenotypic description of GBS III ST17 as hypervirulent clone (43-47). A recently published longitudinal study found that in LOD, GBS and other bacteria isolated from the blood of preterm infants genetically matched clones previously found in the patients' stool (48). Accordingly, in many cases, LOD likely results from systemic spread of intestinal GBS, and not directly from vertical or horizontal transmission. Nevertheless, postnatal exposure with maternal GBS III ST17, e.g., via breast milk, appears to underlie some sepsis cases (49).

For the development of sepsis by GBS spreading from the intestine, the bacterium has to undertake three consecutive steps: (i) colonization of the colon and potentially the small intestine, (ii) translocation across the intestinal epithelium, and (iii) immune evasion preventing GBS clearance from the blood stream (summarized in Table 1).

The first and pivotal step in GBS colonization is adhesion. Adhesion factors are expressed on the bacterial surface and allow GBS to bind to extracellular matrix proteins and epithelial cells of the colon and the genital tract resulting in biofilm formation (50, 51). Adhesion factors can additionally promote invasion, either by disruption of the epithelial cell layer or by modulation of the epithelial cytoskeleton and the junctional protein assembly, which in turn allows for paracellular translocation (52-55).

Two adhesion factors mediate attachment to the extracellular matrix. They are named according to their specific ligand: (i) fibrinogen-binding proteins and (ii) laminin-binding proteins (Lmb). While fibrinogen-binding protein A (FbsA) promotes adhesion, fibrinogen-binding-protein $\mathrm{B}$ (FbsB) mediates GBS invasion into host cells. FbsA and FbsB bind to both immobilized and soluble fibrinogen $(56,57)$. Bacterial attachment to extracellular matrix via Lmb seems important for GBS translocation across the intestinal epithelium and the blood-brain barrier $(58,59)$. Furthermore, the GBS surface adhesin BsaB binds to fibronectin (60). However, whether BsaB contributes to GBS invasion or mainly promotes colonization with GBS via its biofilm enhancing effects has not been fully resolved, yet.

Another group of GBS adhesion factors is characterized by the highly conserved LPxTG (Leu-Pro-X-Thr-Gly) motif at the Cterminus (61). GBS LPxTG is cleaved between Thr and Gly by the transpeptidase Sortase A, which covalently binds GBS to the cell wall and thus promotes both colonization and invasion (62). The first group of the LPxTG containing adhesion factors is the family of Alpha C proteins, which are encoded by the bca (group B, C protein alpha) gene and expressed on most strains of serotype Ia, Ib, and II (63). Alpha C proteins are further characterized by long tandem repeating elements, which allow antigenic variations, and a conserved $\mathrm{N}$-terminal domain, encoding 185 amino acids (61, 6467). GBS isolated from mothers who recently delivered a child with invasive GBS disease show increased expression of alpha $\mathrm{C}$ protein 
Table 1 | GBS virulence factors and their role in transition from colonization to invasive disease

\begin{tabular}{|c|c|c|c|c|c|}
\hline $\begin{array}{ll}\text { Virulence factor } & \text { Mechanism } \\
\end{array}$ & Colonization & Adhesion & Invasion & $\begin{array}{l}\text { Immune } \\
\text { evasion }\end{array}$ & Neurotropism \\
\hline Fibrinogen binding protein $\mathrm{A}(\mathrm{Fbs} \mathrm{A})$ & + & + & & & \\
\hline Fibrinogen binding protein $\mathrm{B}(\mathrm{FbsB})$ & & & + & & \\
\hline Laminin binding protein (Lmb) & & & + & & + \\
\hline GBS surface adhesion (BsaB) & + & + & $(+)$ & & \\
\hline Alpha $\mathrm{C}$ proteins $(\mathrm{ACP})$ & + & + & + & + & \\
\hline Serine rich repeat proteins (Srr) & + & + & + & & \\
\hline Pili & + & + & + & + & + \\
\hline Hypervirulent GBS adhesiin (HvgA) & + & + & + & $(+)$ & + \\
\hline ß-hemolysin/cytolysin (ß-H/C) & + & + & + & + & + \\
\hline Capsular polysaccharides (CPS) & & & & + & \\
\hline Streptococcal C5a peptidaseof GBS (ScpB) & & & & + & \\
\hline GBS immunogenic bacteria adhesion (BibA) & & & & + & \\
\hline Factor $\mathrm{H}$ & & & & + & \\
\hline IgA-binding beta-antigen & & & & + & \\
\hline D-alanylation & & & & + & \\
\hline Superoxide dismutase (SodA) & & & & + & \\
\hline
\end{tabular}

tandem repeats ("aa"). This is associated with increased susceptibility to opsonophagocytic antibody-mediated killing as compared to the GBS isolated previously from the respective newborn infant with sepsis (67). In line with these observations, low tandem repeat expression during infections seems to impair the specific antibody response and antibody-mediated killing (61, 64, 65, 68, 69). Furthermore, GBS alpha C proteins can promote invasion of human epithelial cells via $\alpha 1 \beta 1$-integrin binding (66).

The second group of LPxTG containing adhesion factors are serine-rich repeat (Srr) proteins, which interact with human keratin (Srr-1) and which enhance GBS virulence in mice (Srr-2) (70). Only recently, fibrinogen has been identified as Srr binding partner (71). Interestingly, while highly virulent serotype III strains express Srr-2 (70, 71), other GBS strains express Srr-1 (serotype Ia, Ib, Ic, II, and V).

Additional structures involved in adhesion are Pili, which were first described in GBS in 2005 (72). Pili promote colonization of epithelial cell surfaces, support biofilm formation, and facilitate translocation across the blood-brain barrier (51). They consist of a major shaft subunit, the backbone protein BP, which is critical for pilus assembly, and the two ancillary proteins AP1 and AP2 (73). Three pilus islands (PI1, PI2a, and PI2b) were identified. In mice, PI2a is essential for GBS virulence (74), and pilus island specific antibodies enhance opsonophagocytic killing and protect from sepsis $(75,76)$. Yet, development of pilus structures as vaccine candidates was hampered by variable pilus expression in GBS $(75,76)$.

Comparative expression analysis between clones with different clinical virulence (based on the disease phenotype in infants) led to the identification of the surface-anchored hypervirulent GBS adhesin (HvgA) as a specific virulence factor in GBS ST17 (9). Similar to pili, HvgA mediates both colonization and invasion in the intestine and confers meningeal tropism in neonatal mice $(9,10)$. Interestingly, GBS isolated from blood and cerebrospinal fluid during invasive disease express higher HvgA levels as compared to GBS cultured in vitro, indicating upregulation of HvgA expression during infection (9). Moreover, the ability of GBS ST17 to spread from the intestinal lumen is linked to the age of the mice, since $60-70 \%$ of preweaning mice (15-21 days old) succumb after enteral infection with $h v g A$-expressing GBS, whereas mice $\geq 4$ weeks are protected (9). An experiment of nature, which we recently observed, suggests that yet to be identified changes in GBS virulence likely contribute to sepsis onset. An HvgA-positive strain of GBS, which was transmitted probably through breast milk from the mother, induced two episodes of sepsis each in twins, i.e., a total of four episodes, in a synchronous fashion. In 
all cases, sepsis started with soft-tissue infections of the lower oral cavity border, which implies a temporarily highly invasive and reproducible behavior of GBS (49).

Group B Streptococcus translocation across the epithelial barrier is further facilitated by the virulence factor $\beta$-hemolysin/cytolysin $(\beta-\mathrm{H} / \mathrm{C})(77-79) . \beta-\mathrm{H} / \mathrm{C}$ induces cytolysis in eukaryotic cells and promotes bacterial invasion across epithelial and endothelial walls, including the blood-brain barrier. In mice, $\beta$-H/C induces placental inflammation and preterm birth, independently of bacterial ascension (80). $\beta$-H/C-deficient GBS show impaired virulence in various in vivo models including pneumonia, sepsis, and meningitis $(77,79,81)$. However, at sublytic concentrations, $\beta-\mathrm{H} / \mathrm{C}$ drives expression of the anti-inflammatory cytokine IL-10 and inhibits both IL-12 and NOS2 expression in GBS-infected macrophages (82). Thus expression levels of $\beta-\mathrm{H} / \mathrm{C}$ appear to determine whether GBS stabilizes its niche to allow for colonization, or whether GBS becomes invasive. Additionally, the pore-forming toxin and co-hemolysin CAMP factor may contribute to GBS pathogenesis under certain circumstances $(83,84)$, but is dispensable for systemic virulence (83-86).

Distinct types of capsular polysaccharides (CPS), which underlie the serotyping system, allow for immune evasion, since $\alpha 2 \rightarrow 3$ linked sialic acid modifications use molecular mimicry with host sugar epitopes. Direct binding to immunoglobulin-like lectins (Siglecs) on leukocytes inhibits complement C3 activation on the bacterial surface (87-89). Complement inactivation is further supported by ScpB (Streptococcal C5a peptidase of GBS)-mediated proteolytic C5a inactivation (90) and reduced complement binding through the inhibitory factors BibA (GBS immunogenic bacterial adhesin) (91) and factor $\mathrm{H}$ (92). Immunoglobulin binding, an essential precondition for opsonophagocytosis, is hampered by the IgA-binding beta-antigen of the c protein complex, which recognizes the Fc region of human immunoglobulin A (93). GBS evades phagolysosomal processing by neutralizing reactive oxygen species via BibA, $\beta-\mathrm{H} / \mathrm{C}$, superoxide dismutase (SodA), and additional unknown factors $(77,78,91,94-96)$. Similarly, binding of intestinal and circulating antimicrobial peptides can be suppressed by intrinsic GBS mechanisms such as D-alanylation of lipteichoic acid, which is catalyzed by the dlt operon. Down-modulation of $\mathrm{D}$-alanylation decreases the negative surface charge, which in turn is important for cationic binding of antimicrobial peptides such as colistin (97).

\section{REGULATION OF GBS VIRULENCE}

As outlined above, the human intestine is the natural niche for GBS. In other words, GBS thrives in healthy hosts. Accordingly, it is for the benefit of both GBS and the host if GBS is kept in a colonization state and does not exhibit its aggressive traits. Thus, expression of virulence factors in GBS must be tightly regulated. Two-component control systems, which typically consist of a membrane-linked histidine kinase sensor and a cytoplasmatic transcriptional element, are common in bacteria and more than 4000 regulatory systems have been described $(98,99)$. In GBS, CovS/CovR (Control of virulence Sensor/Regulator) tightly regulates the expression of pili, BsaB, $h v g A, c y I E$, which is involved in $\beta-H / C$ expression, and many other genes $(60,100,101)$. CovS acts as a $\mathrm{pH}$ sensor. In an acidic milieu, such as the vagina, CovS remains in an autophosphorylated state and activates the regulatory domain CovR by transphosphorylation at the aspartate residue D53. Subsequently, the phosphorylated form of CovR acts as a repressor. An increase in $\mathrm{pH}$ reduces CovS phosphorylation and induces the expression of $\beta-\mathrm{H} / \mathrm{C}$ (102). In addition to $\mathrm{pH}$, high glucose levels, peripheral insulin resistance, and passage through the intestine modulate CovR/CovS in mice (103-105). Inactivation of the CovR system increases GBS adherence to epithelial cells (106) by upregulation of PI1 expression (104). In line with this, GBS mutant in either CovS or CovR show increased hemolysis and approximately 80-fold upregulated HvgA (9).

Next to CovS, the serine/threonine kinase Stk1 acts as a sensor for environmental stimuli. Stk1 activation leads to phosphorylation of CovR at threonine 65. GBS with Stk1 mutations show reduced expression of $\beta-\mathrm{H} / \mathrm{C}$; susceptibility to opsonophagocytic killing and oxidative stress is increased $(107,108)$. Thus, while CovR phosphorylation at the aspartate residue D53 by CovS leads to protein activation associated with reduced virulence, Stk1mediated phosphorylation at the threonine residue T63 increases the expression of $\beta-\mathrm{H} / \mathrm{C}$ (108). Abx1, an additional partner within the CovS/CovR system, displays complex counterbalancing activity (107-109). As transmembrane protein Abx1 holds direct proximity to CovS, which it partially antagonizes. Both functional loss and overexpression of Abx1 hampers GBS virulence expression, and Abxl expression itself is critically dependent on functional $\beta-\mathrm{H} / \mathrm{C}$ formation (109). This system "fine tunes" GBS and may explain, at least in part, the loss of virulence of hyperhemolytic mutants due to CovR inactivation or Abxl overexpression.

In summary, the CovS/CovR system inhabits a central role in the control of GBS virulence. It is tightly regulated, and specific environmental factors allow for subtle adaptation of the bacterial phenotype to the site of colonization/infection.

\section{THE HOST SITE: TOLL-LIKE RECEPTORS AND THE INFLAMMASOME MEDIATE HOST RESISTANCE AND FATAL INFLAMMATION}

Neonatal mice are exquisitely sensitive for GBS. Less than 100 bacteria injected s.c. constitute the lethal dose $90 \%$. Under these conditions, disease is at least partially immune mediated, since the inflammatory cytokine TNF alone accounts for approximately half of the deaths (110). An important ligand receptor interaction resulting in TNF formation is that between diacylated lipoproteins and Toll-like receptors (TLR)2/6 heterodimers (111). Deletion of the diacyl transferase Lgt from GBS results in the same change in GBS sepsis phenotype as that observed in conventional TLR2 knock-out mice. The TLR-dependent recognition of bacterial lipopeptides can be assumed to primarily occur on the cell surface (112), although endosomal recognition of lipopeptides has recently been demonstrated (113). Next to lipoproteins, nucleic acids from GBS potently activate inflammatory genes in phagocytes. At least three distinct signaling pathways engaged by GBS nucleic acids have been identified. First, intracellular recognition of GBS DNA by one or several currently unknown cytosolic receptors results in the formation of type I interferons in a TBK1 and IRF3-dependent fashion (114) (IFN pathway). Second, two pathways involve recognition of GBS RNA. The first engages an UNC-93B- and MyD88-dependent pathway $(115,116)$ (TLR 
pathway), which has been shown to utilize TLR7 in dendritic cells (117), whereas the cognate TLR in macrophages is still elusive (116). The second pathway involves cytosolic sensing of RNA and $\beta$-hemolysin through the intracellular NLRP3 inflammasome (NOD-like receptor family, pyrin domain containing 3), which mediates IL-1 $\beta$ maturation in macrophages and dentritic cells $(118,119)$. Accordingly, in a mouse GBS sepsis model, NLRP3deficiency is associated with significantly increased lethality (118, 119). It appears that NLRP3 and GBS RNA closely interact in the cytosol, and disruption of the GBS bearing phagosomes allows NLRP3 and GBS RNA to get into close contact (118). Discrimination of bacterial RNA from human ribosomal and transfer RNA appears to depend at least partially on the RNA methylation status (120). In S. aureus, methylated ribosomal RNA is recognized by TLR13, a TLR that currently lacks a human homolog. Accordingly, $S$. aureus strains that have acquired the methylase erm, conferring erythromycin resistance, have lost their TLR13-activating potential (121).

In summary, sensing of GBS lipoproteins and nucleic acids mediates activation of macrophages and dendritic cells and contributes to resistance against GBS and disease progression during sepsis. Yet, the contribution of these systems to containing GBS at mucosal sites is currently unclear.

\section{IL-10 AND ITS ROLE IN GBS COLONIZATION AND DISEASE}

Very recently, the glycolytic enzyme glycerinaldehyde-3phosphate-dehydrogenase (GAPDH) from GBS was shown to subvert immunity by inducing IL-10 $(103,122,123)$. This adds to the kaleidoscope of functions of an enzyme, which is largely known for its role in bacterial energy generation (124-127) (summarized in Figure 1). GBS GAPDH is expressed as a surface molecule and in a soluble form $(126,128,129)$. In mice, it directly activates $\mathrm{B}$ - and, to a lower extent, T-lymphocytes and induces the maturation of anti-GAPDH Ig-secreting plasma cells (130). Both endogenous and systemically administered GAPDH specific antibodies significantly reduce intestinal GBS colonization and protect from invasion of GAPDH-expression GBS strains. On the other hand, administration of recombinant GAPDH induces systemic release of IL-10 in mice and increases susceptibility to invasive GBS disease and bacterial invasion of per se non-invasive strains $(82,122,130,131)$. In line with these observations, IL-10-deficient mice are protected from invasive GBS disease and show improved survival in various sepsis models $(122,131-133)$. These effects are further consistent with the observation that reduced IL-10 activity increases neutrophil recruitment and bacterial killing (122, 130, 131). However, in earlier investigations, IL-10 given before infection protected neonatal mice from GBS sepsis and correlated

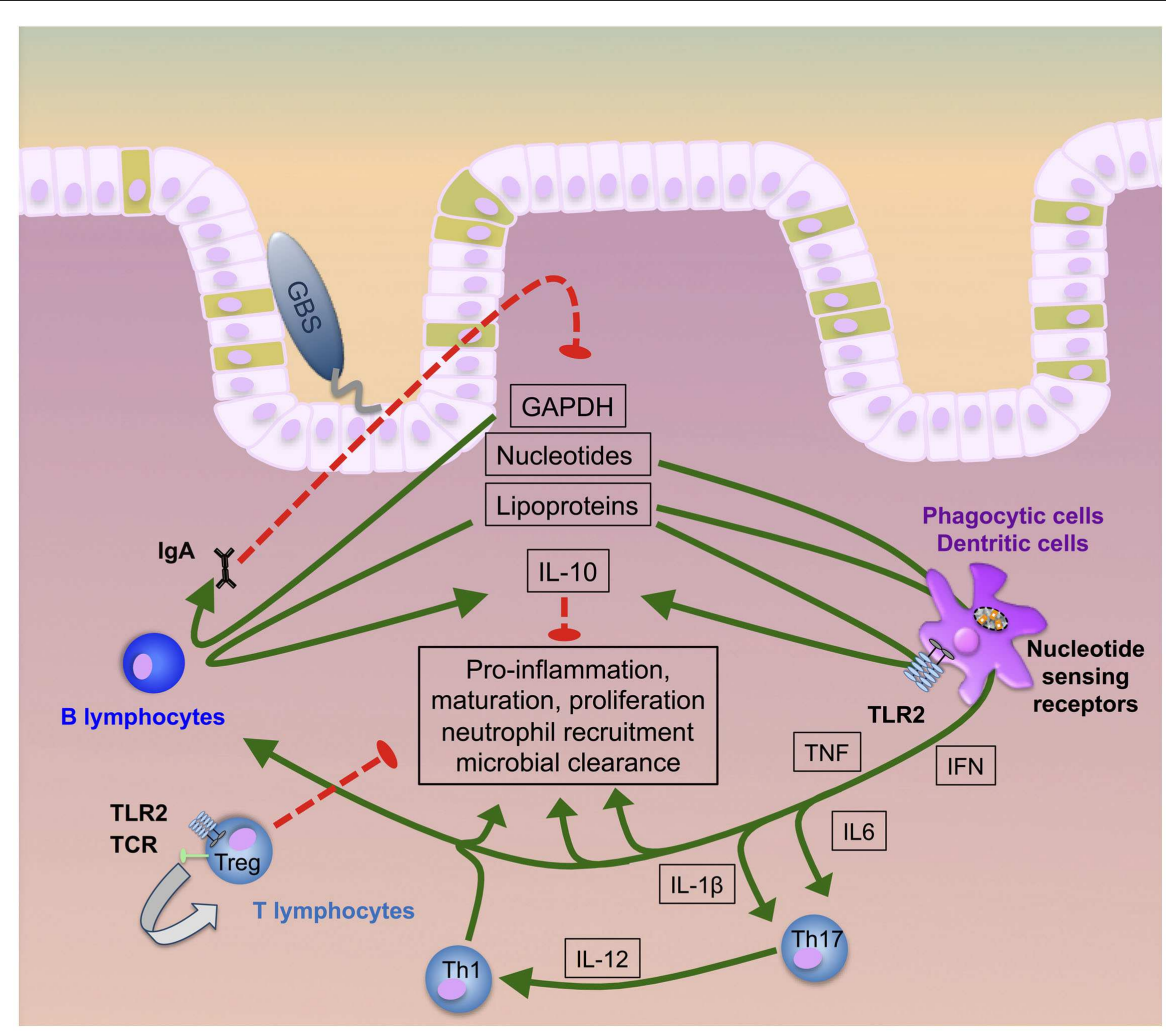

FIGURE 1 | GBS transition to invasive disease. GBS lipoproteins, GAPDH, and nucleic acids majorly contribute to intestinal immune activation inducing pro-inflammatory responses, neutrophil recruitment, cellular proliferation, maturation and, finally, microbial clearance. Early induction of specific antibody release by $B$ plasma cells and IL-10 secretion by both B-lymphocytes and phagocytes act as a negative feedback loop to counter-regulate hyperinflammation. Uncontrolled increase of IL-10, in contrast, hampers neutrophil recruitment and bacterial elimination. At the same time, T-lymphocytes can directly interact with GBS ligands or receive pro-inflammatory signals via monocytic cytokines. While Th1 and Th17 cells promote infection control, activation of regulatory $T$ cells prevents hyperinflammation and supports post-infectious healing. 
with TNF suppression and improved survival (134). This effect was strictly dependent on the time of IL-10 application, since simultaneous or post-infectious administration failed to mediate protective effects. In contrast, in LPS-TLR4 induced septic shock models IL-10 improved survival even when given simultaneously with or early after LPS administration $(133,135,136)$. Monocytes, macrophages, and T- and B-lymphocytes are all sources of IL-10 (Figure 1). IL-10 induction in macrophages depends on JNK signaling, which in turn is critical for the outcome in GBS sepsis (137-140). Expression of IL-10R (IL-10 receptor) and TGFBR1/TGFBR2 (TGF-beta receptors 1 and 2) and the presence of their specific ligands are pivotal to preserve immune homeostasis (141-144). In vitro, IL-10 reduces NF-kB signaling and the expression of TLRs, MyD88, and TIR in resident intestinal macrophages (iM) and circulating monocytes (145). In neonatal mice, the inflammatory program of iM is shifted toward IL-10 as the signature effector molecule via TGF-beta as a signaling intermediate (146). Patients with defects in the IL-10 or IL-10R gene develop severe, early-onset inflammatory bowel disease. Thus IL10 is critical for intestinal inflammation control (147-149). Since, mice with a targeted deletion of STAT3 in macrophages and neutrophils (LysMcre/Stat $3^{\text {flox/- }}$ ) develop spontaneous enterocolitis, it seems that tissue macrophages constitute the major source of IL-10 (150). Macrophage expression of IL-10 is dependent on TLR-dependent sensing of the microbiota and signal transduction by the adapter protein MyD88 (151). The multitude of functions of IL-10, its site-specific functions and the dynamics in its inducible effects all contribute to its highly complex role in stabilizing the interface between GBS and host.

\section{GBS IN (TRANSIENT) IMMUNODEFICIENCY}

The so-called human model, where patients with monogenetic variations provide clues for the role of cell specific immunity, has been powerful in better understanding host-microbe interactions leading to coexistence and disease. An intriguing example is MyD88/IRAK-4-deficiency with its specific susceptibility to staphylococci, streptococci, and Pseudomonas spp. However, the search for monogenetic immunodeficiency disorders underlying susceptibility to invasive GBS infections has only been partially successful so far. One patient with very late-onset GBS sepsis suffering from IRAK-4 deficiency has been reported, supporting that cellular innate immunity and the TLR system are important for resistance against GBS (152-154). It can be expected that whole exome or genome analysis in families with GBS sepsis will provide further information in this regard in the future.

Next to the genetic absence of specific factors in cellular innate immunity, transient changes in innate immunity may underlie susceptibility to invasive GBS disease in newborn infants. Neonatal sepsis is characterized by excessive inflammation, since high levels of pro-inflammatory cytokines can be measured in the serum of newborn infants suffering from invasive GBS disease. In vitro, PBMC from healthy neonates rapidly respond to GBS with the formation of large amounts of IL-6, TNF, IL-8, and IL$1 \beta$ (155-157). Since insulin suppresses the cytokine formation in response to GBS, peripheral insulin resistance present in newborn infants and particularly during sepsis may promote the inflammatory process (158). Excessive stimulation of immune cells may be further enhanced by a reduction of antimicrobial phagocyte properties, which are markedly impaired in neonates and may allow for pathogen persistence and failure to contract the immune response (159-161). GBS persistence likely results from reduced G-actin polarization and L-selectin expression in newborn, especially preterm infants, which results in impaired neutrophil adhesion and migration $(162,163)$. Moreover, low expression of opsonizing complement components, immunoglobulins, reactive oxygen species, the integrin CD11b/CD18, and Fc-gamma receptors II and III (164-166) and a predominant polarization of T-lymphocytes toward Th2 and Th17 may overall interfere with timely and rigorous clearance of invasive GBS (161, 167-173). How can the high levels of IL-10 in neonatal GBS infections, as observed in mice (174-177) and humans (178-180), be explained in view of the generally highly inflammatory state? Although conclusive evidence on this matter is lacking, it is tempting to speculate that the negative impact of IL-10 on neutrophil function, which allows for pathogen expansion, overrides the direct anti-inflammatory properties of IL-10 on the mononuclear phagocyte system. In this scenario, the net result in neonatal GBS sepsis is inflammatory despite high IL-10 levels.

\section{CONCLUSION}

Group B Streptococcus comprises several regulatory systems that respond to the microenvironment and, by steering adhesion and virulence factors, allow for colonization of mucosal niches in the genital and (lower) intestinal tract. Colonization is further propagated by the GBS-intrinsic ability to manipulate local cellular immunity. Yet, under only partially understood conditions GBS looses its colonizing trait and invades the host. Then, immune mechanisms that usually stabilize the natural GBS niche may lead to detrimental immunopathology. Rather subtle changes on the single immune cell level in newborn infants appear to facilitate the escalation from a beneficial site-specific response to sepsis and meningitis. Better understanding of the dynamic expression of virulence traits in GBS, and of the cellular immunology that shapes the GBS niche, will hopefully pave the way for preventing livelong disabilities inflicted by a normal component of the microbiota.

\section{REFERENCES}

1. Matsubara K, Yamamoto G. Invasive group B streptococcal infections in a tertiary care hospital between 1998 and 2007 in Japan. Int J Infect Dis (2009) 13:679-84. doi:10.1016/j.ijid.2008.10.007

2. Stoll BJ, Hansen NI, Bell EF, Shankaran S, Laptook AR, Walsh MC, et al. Neonatal outcomes of extremely preterm infants from the NICHD neonatal research network. Pediatrics (2010) 126:443-56. doi:10.1542/peds.2009-2959

3. Stoll BJ, Hansen NI, Sánchez PJ, Faix RG, Poindexter BB, Van Meurs KP, et al. Early onset neonatal sepsis: the burden of group B streptococcal and E. coli disease continues. Pediatrics (2011) 127:817-26. doi:10.1542/peds.2010-2217

4. Skoff TH, Farley MM, Petit S, Craig AS, Schaffner W, Gershman K, et al. Increasing burden of invasive group B streptococcal disease in nonpregnant adults, 1990-2007. Clin Infect Dis (2009) 49(1):85-92. doi:10.1086/599369

5. Trijbels-Smeulders MA, Kimpen JL, Kollée LA, Bakkers J, Melchers W, Spanjaard L, et al. Serotypes, genotypes, and antibiotic susceptibility profiles of group B streptococci causing neonatal sepsis and meningitis before and after introduction of antibiotic prophylaxis. Pediatr Infect Dis J (2006) 25:945-8. doi:10.1097/01.inf.0000237821.65559.08

6. Trijbels-Smeulders MA, Kollée LA, Adriaanse AH, Kimpen JL, Gerards LJ. Neonatal group B streptococcal infection: incidence and strategies for prevention in Europe. Pediatr Infect Dis J (2004) 23:172-3. doi:10.1097/01.inf. $0000111212.94913 .5 \mathrm{f}$ 
7. Kunze M, Ziegler A, Fluegge K, Hentschel R, Proempeler H, Berner R. Colonization, serotypes and transmission rates of group B streptococci in pregnant women and their infants born at a single University Center in Germany. J Perinat Med (2011) 39:417-22. doi:10.1515/jpm.2011.037

8. Fluegge K, Siedler A, Heinrich B, Schulte-Moenting J, Moennig MJ, Bartels DB, et al. Incidence and clinical presentation of invasive neonatal group B streptococcal infections in Germany. Pediatrics (2006) 117:e1139-45. doi:10.1542/ peds.2005-2481

9. Tazi A, Disson O, Bellais S, Bouaboud A, Dmytruk N, Dramsi S, et al. The surface protein HvgA mediates group B Streptococcus hypervirulence and meningeal tropism in neonates. J Exp Med (2010) 207(11):2313-22. doi:10.1084/jem.20092594

10. Tazi A, Bellais S, Tardieux I, Dramsi S, Trieu-Cuot P, Poyart C. Group B Streptococcus surface proteins as major determinants for meningeal tropism. Curr Opin Microbiol (2012) 15(1):44-9. doi:10.1016/j.mib.2011.12.002

11. Lewin EB, Amstey MS. Natural history of group B Streptococcus colonization and its therapy during pregnancy. Am J Obstet Gynecol (1981) 139(5):512-5.

12. Eckburg PB, Bik EM, Bernstein CN, Purdom E, Dethlefsen L, Sargent M, et al. Diversity of the human intestinal microbial flora. Science (2005) 308(5728):1635-8. doi:10.1126/science.1110591

13. Zoetendal EG, Akkermans AD, De Vos WM. Temperature gradient gel electrophoresis analysis of $16 \mathrm{~S}$ rRNA from human fecal samples reveals stable and host-specific communities of active bacteria. Appl Environ Microbiol (1998) 64(10):3854-9.

14. Garrett WS, Gordon JI, Glimcher LH. Homeostasis and inflammation in the intestine. Cell (2010) 140(6):859-70. doi:10.1016/j.cell.2010.01.023

15. Masanta WO, Heimesaat MM, Bereswill S, Tareen AM, Lugert R, Groß U, et al. Modification of intestinal microbiota and its consequences for innate immune response in the pathogenesis of campylobacteriosis. Clin Dev Immunol (2013) 2013:526860. doi: $10.1155 / 2013 / 526860$

16. Neut C, Bezirtzoglou E, Romond C, Beerens H, Delcroix M, Noel AM. Bacterial colonization of the large intestine in newborns delivered by cesarean section. Zentralbl Bakteriol Mikrobiol Hyg A (1987) 266(3-4):330-7.

17. Bennet R, Nord CE. Development of the faecal anaerobic microflora after caesarean section and treatment with antibiotics in newborn infants. Infection (1987) 15(5):332-6. doi:10.1007/BF01647733

18. Penders J, Thijs C, Vink C, Stelma FF, Snijders B, Kummeling I, et al. Factors influencing the composition of the intestinal microbiota in early infancy. Pediatrics (2006) 118(2):511-21. doi:10.1542/peds.2005-2824

19. Guaraldi F, Salvatori G. Effect of breast and formula feeding on gut microbiota shaping in newborns. Front Cell Infect Microbiol (2012) 2:94. doi:10. 3389/fcimb.2012.00094

20. Rogier EW, Frantz AL, Bruno ME, Wedlund L, Cohen DA, Stromberg AJ, et al Secretory antibodies in breast milk promote long-term intestinal homeostasis by regulating the gut microbiota and host gene expression. Proc Natl Acad Sci U S A (2014) 111(8):3074-9. doi:10.1073/pnas.1315792111

21. Palmer C, Bik EM, DiGiulio DB, Relman DA, Brown PO. Development of the human infant intestinal microbiota. PLoS Biol (2007) 5(7):e177. doi:10.1371/journal.pbio.0050177

22. Civardi E, Garofoli F, Mazzucchelli I, Angelini M, Manzoni P, Stronati M. Enteral nutrition and infections: the role of human milk. Early Hum Dev (2014) 90(Suppl 1):S57-9. doi:10.1016/S0378-3782(14)70019-2

23. Wold AE, Adlerberth I. Breast feeding and the intestinal microflora of the infant - implications for protection against infectious diseases. Adv Exp Med Biol (2000) 478:77-93. doi:10.1007/0-306-46830-1_7

24. Jakaitis BM, Denning PW. Human breast milk and the gastrointestinal innate immune system. Clin Perinatol (2014) 41(2):423-35. doi:10.1016/j.clp.2014 02.011

25. Cederlund A, Kai-Larsen Y, Printz G, Yoshio H, Alvelius G, Lagercrantz H, et al. Lactose in human breast milk an inducer of innate immunity with implications for a role in intestinal homeostasis. PLoS One (2013) 8(1):e53876. doi:10.1371/journal.pone.0053876

26. Stewart CJ, Marrs EC, Nelson A, Lanyon C, Perry JD, Embleton ND, et al. Development of the preterm gut microbiome in twins at risk of necrotising enterocolitis and sepsis. PLoS One (2013) 8(8):e73465. doi:10.1371/journal pone.0073465

27. Azad MB, Konya T, Maughan H, Guttman DS, Field CJ, Chari RS, et al Gut microbiota of healthy Canadian infants: profiles by mode of delivery and infant diet at 4 months. CMAJ (2013) 185(5):385-94. doi:10.1503/cmaj. 121189

28. Stappenbeck TS, Hooper LV, Gordon JI. Developmental regulation of intestinal angiogenesis by indigenous microbes via Paneth cells. Proc Natl Acad Sci U S A (2002) 99(24):15451-5. doi:10.1073/pnas.202604299

29. Xu J, Gordon JI. Honor thy symbionts. Proc Natl Acad Sci U S A (2003) 100(18):10452-9. doi:10.1073/pnas.1734063100

30. Hooper LV, Midtvedt T, Gordon JI. How host-microbial interactions shape the nutrient environment of the mammalian intestine. Annu Rev Nutr (2002) 22:283-307. doi:10.1146/annurev.nutr.22.011602.092259

31. MacDonald TT, Gordon JN. Bacterial regulation of intestinal immune responses. Gastroenterol Clin North Am (2005) 34(3):401-12, vii-viii. doi:10. 1016/j.gtc.2005.05.012

32. Fukuda S, Toh H, Hase K, Oshima K, Nakanishi Y, Yoshimura K, et al. Bifidobacteria can protect from enteropathogenic infection through production of acetate. Nature (2011) 469(7331):543-7. doi:10.1038/nature09646

33. Maynard CL, Elson CO, Hatton RD, Weaver CT. Reciprocal interactions of the intestinal microbiota and immune system. Nature (2012) 489(7415):231-41. doi:10.1038/nature 11551

34. Jackson LA, Hilsdon R, Farley MM, Harrison LH, Reingold AL, Plikaytis BD, et al. Risk factors for group B streptococcal disease in adults. Ann Intern Med (1995) 123(6):415-20. doi:10.7326/0003-4819-123-6-199509150-00003

35. Anthony BF, Carter JA, Eisenstadt R, Rimer DG. Isolation of group B streptococci from the proximal small intestine of adults. J Infect Dis (1983) 147(4):776. doi:10.1093/infdis/147.4.776

36. Kneafsey PD, Kelly JK, Church DL, Rapp EF, Lafreniere R. Phlegmonous duodenitis complicating multiple myeloma: a successfully treated case. Am J Gastroenterol (1987) 82(12):1322-5.

37. Krohn MA, Hillier SL, Baker CJ. Maternal peripartum complications associated with vaginal group B streptococci colonization. J Infect Dis (1999) 179(6):1410-5. doi:10.1086/314756

38. Regan JA, Klebanoff MA, Nugent RP, Eschenbach DA, Blackwelder WC, Lou $\mathrm{Y}$, et al. Colonization with group B streptococci in pregnancy and adverse outcome. VIP Study Group. Am J Obstet Gynecol (1996) 174(4):1354-60. doi:10.1016/S0002-9378(96)70684-1

39. Lamy M-C, Dramsi S, Billoët A, Réglier-Poupet H, Tazi A, Raymond J, et al. Rapid detection of the "highly virulent" group B Streptococcus ST-17 clone. Microbes Infect (2006) 8(7):1714-22. doi:10.1016/j.micinf.2006.02.008

40. Phares CR, Lynfield R, Farley MM, Mohle-Boetani J, Harrison LH, Petit S, et al. Epidemiology of invasive group B streptococcal disease in the United States, 1999-2005. JAMA (2008) 299(17):2056-65. doi:10.1001/jama.299.17.2056

41. Baker CJ, Barrett FF. Transmission of group B streptococci among parturient women and their neonates. J Pediatr (1973) 83(6):919-25. doi:10.1016/S00223476(73)80524-4

42. Haque KN. Definitions of bloodstream infection in the newborn. Pediat Crit Care Med (2005) 6(3 Suppl):S45-9. doi:10.1097/01.PCC.0000161946. 73305.0A

43. Poyart C, Réglier-Poupet H, Tazi A, Billoët A, Dmytruk N, Bidet P, et al. Invasive group B streptococcal infections in infants, France. Emerg Infect Dis (2008) 14(10):1647-9. doi:10.3201/eid1410.080185

44. Brochet M, Couvé E, Zouine M, Vallaeys T, Rusniok C, Lamy M-C, et al. Genomic diversity and evolution within the species Streptococcus agalactiae. Microbes Infect (2006) 8(5):1227-43. doi:10.1016/j.micinf.2005.11.010

45. Musser JM, Mattingly SJ, Quentin R, Goudeau A, Selander RK. Identification of a high-virulence clone of type III Streptococcus agalactiae (group B Streptococcus) causing invasive neonatal disease. Proc Natl Acad Sci U S A (1989) 86(12):4731-5. doi:10.1073/pnas.86.12.4731

46. Jones N, Bohnsack JF, Takahashi S, Oliver KA, Chan M-S, Kunst F, et al. Multilocus sequence typing system for group B Streptococcus. J Clin Microbiol (2003) 41(6):2530-6. doi:10.1128/JCM.41.6.2530-2536.2003

47. Manning SD, Springman AC, Lehotzky E, Lewis MA, Whittam TS, Davies HD. Multilocus sequence types associated with neonatal group B streptococcal sepsis and meningitis in Canada. J Clin Microbiol (2009) 47(4):1143-8. doi:10.1128/JCM.01424-08

48. Carl MA, Ndao IM, Springman AC, Manning SD, Johnson JR, Johnston BD, et al. Sepsis from the gut: the enteric habitat of bacteria that cause lateonset neonatal bloodstream infections. Clin Infect Dis (2014) 58(9):1211-8. doi:10.1093/cid/ciu084 
49. Elling AR, Hufnagel M, de Zoysa A, Lander F, Zumstein K, Krueger M, et al. Synchronous recurrence of group B streptococcal late-onset sepsis in twins. Pediatrics (2014) 133(5):1-5. doi:10.1542/peds.2013-0426

50. Borges S, Silva J, Teixeira P. Survival and biofilm formation by group B streptococci in simulated vaginal fluid at different pHs. Antonie Van Leeuwenhoek (2012) 101(3):677-82. doi:10.1007/s10482-011-9666-y

51. Konto-Ghiorghi Y, Mairey E, Mallet A, Duménil G, Caliot E, Trieu-Cuot $\mathrm{P}$, et al. Dual role for pilus in adherence to epithelial cells and biofilm formation in Streptococcus agalactiae. PLoS Pathog (2009) 5(5):e1000422. doi:10.1371/journal.ppat.1000422

52. Nizet V, Gibson RL, Chi EY, Framson PE, Hulse M, Rubens CE. Group B streptococcal beta-hemolysin expression is associated with injury of lung epithelial cells. Infect Immun (1996) 64(9):3818-26.

53. Gibson RL, Nizet V, Rubens CE. Group B streptococcal beta-hemolysin promotes injury of lung microvascular endothelial cells. Pediatr Res (1999) 45(5 Pt 1):626-34. doi:10.1203/00006450-199905010-00003

54. Duménil G, Nassif X. Extracellular bacterial pathogens and small GTPases of the Rho family: an unexpected combination. Curr Top Microbiol Immunol (2005) 291:11-28. doi:10.1007/3-540-27511-8_2

55. Soriani M, Santi I, Taddei A, Rappuoli R, Grandi G, Telford JL. Group B Streptococcus crosses human epithelial cells by a paracellular route. J Infect Dis (2006) 193(2):241-50. doi:10.1086/498982

56. Jacobsson K. A novel family of fibrinogen-binding proteins in Streptococcus agalactiae. Vet Microbiol (2003) 96(1):103-13. doi:10.1016/S0378-1135(03) 00206-2

57. Schubert A, Zakikhany K, Schreiner M, Frank R, Spellerberg B, Eikmanns BJ, et al. A fibrinogen receptor from group B Streptococcus interacts with fibrinogen by repetitive units with novel ligand binding sites. Mol Microbiol (2002) 46(2):557-69. doi:10.1046/j.1365-2958.2002.03177.x

58. Spellerberg B, Rozdzinski E, Martin S, Weber-Heynemann J, Schnitzler N, Lütticken R, et al. Lmb, a protein with similarities to the LraI adhesin family, mediates attachment of Streptococcus agalactiae to human laminin. Infect Immun (1999) 67(2):871-8.

59. Tenenbaum T, Spellerberg B, Adam R, Vogel M, Kim KS, Schroten H. Streptococcus agalactiae invasion of human brain microvascular endothelial cells is promoted by the laminin-binding protein Lmb. Microbes Infect (2007) 9(6):714-20. doi:10.1016/j.micinf.2007.02.015

60. Jiang S, Wessels MR. BsaB, a novel adherence factor of group B Streptococcus. Infect Immun (2014) 82(3):1007-16. doi:10.1128/IAI.01014-13

61. Michel JL, Madoff LC, Olson K, Kling DE, Kasper DL, Ausubel FM. Large, identical, tandem repeating units in the $\mathrm{C}$ protein alpha antigen gene, bca, of group B streptococci. Proc Natl Acad Sci U S A (1992) 89(21):10060-4. doi:10.1073/pnas.89.21.10060

62. Lalioui L, Pellegrini E, Dramsi S, Baptista M, Bourgeois N, Doucet-Populaire F, et al. The SrtA sortase of Streptococcus agalactiae is required for cell wall anchoring of proteins containing the LPXTG motif, for adhesion to epithelial cells, and for colonization of the mouse intestine. Infect Immun (2005) 73(6):3342-50. doi:10.1128/IAI.73.6.3342-3350.2005

63. Madoff LC, Hori S, Michel JL, Baker CJ, Kasper DL. Phenotypic diversity in the alpha C protein of group B streptococci. Infect Immun (1991) 59(8):2638-44.

64. Gravekamp C, Kasper DL, Michel JL, Kling DE, Carey V, Madoff LC. Immunogenicity and protective efficacy of the alpha $\mathrm{C}$ protein of group B streptococci are inversely related to the number of repeats. Infect Immun (1997) 65(12):5216-21

65. Pannaraj PS, Kelly JK, Rench MA, Madoff LC, Edwards MS, Baker CJ. Alpha C protein-specific immunity in humans with group B streptococcal colonization and invasive disease. Vaccine (2008) 26(4):502-8. doi:10.1016/j.vaccine.2007. 11.034

66. Bolduc GR, Madoff LC. The group B streptococcal alpha C protein binds alpha1beta1-integrin through a novel KTD motif that promotes internalization of GBS within human epithelial cells. Microbiology (2007) 153(Pt 12):4039-49. doi:10.1099/mic.0.2007/009134-0

67. Madoff LC, Michel JL, Gong EW, Kling DE, Kasper DL. Group B streptococci escape host immunity by deletion of tandem repeat elements of the alpha C protein. Proc Natl Acad Sci U S A (1996) 93(9):4131-6. doi:10.1073/pnas.93.9.4131

68. Rubens CE, Wessels MR, Heggen LM, Kasper DL. Transposon mutagenesis of type III group B Streptococcus: correlation of capsule expression with virulence. Proc Natl Acad Sci U S A (1987) 84(20):7208-12. doi:10.1073/pnas.84.20.7208
69. Madoff LC, Michel JL, Gong EW, Rodewald AK, Kasper DL. Protection of neonatal mice from group $\mathrm{B}$ streptococcal infection by maternal immunization with beta C protein. Infect Immun (1992) 60(12):4989-94.

70. Seifert KN, Adderson EE, Whiting AA, Bohnsack JF, Crowley PJ, Brady LJ. A unique serine-rich repeat protein (Srr-2) and novel surface antigen (epsilon) associated with a virulent lineage of serotype III Streptococcus agalactiae. Microbiology (2006) 152(4):1029-40. doi:10.1099/mic.0.28516-0

71. Seo HS, Minasov G, Seepersaud R, Doran KS, Dubrovska I, Shuvalova L, et al. Characterization of fibrinogen binding by glycoproteins Srr1 and Srr2 of Streptococcus agalactiae. J Biol Chem (2013) 288(50):35982-96. doi:10.1074/ jbc.M113.513358

72. Lauer P, Rinaudo CD, Soriani M, Margarit I, Maione D, Rosini R, et al. Genome analysis reveals pili in group B Streptococcus. Science (2005) 309(5731):105. doi:10.1126/science. 1111563

73. Rosini R, Rinaudo CD, Soriani M, Lauer P, Mora M, Maione D, et al. Identification of novel genomic islands coding for antigenic pilus-like structures in Streptococcus agalactiae. Mol Microbiol (2006) 61(1):126-41. doi:10.1111/j. 1365-2958.2006.05225.x

74. Papasergi S, Brega S, Mistou M-Y, Firon A, Oxaran V, Dover R, et al. The GBS PI-2a pilus is required for virulence in mice neonates. PLoS One (2011) 6(4):e18747. doi:10.1371/journal.pone.0018747

75. Nuccitelli A, Cozzi R, Gourlay LJ, Donnarumma D, Necchi F, Norais N. Structure-based approach to rationally design a chimeric protein for an effective vaccine against group B Streptococcus infections. Proc Natl Acad Sci U S A (2011) 108(25):10278-83. doi:10.1073/pnas.1106590108

76. Margarit I, Rinaudo CD, Galeotti CL, Maione D, Ghezzo C, Buttazzoni E, et al. Preventing bacterial infections with pilus-based vaccines: the group B Streptococcus paradigm. J Infect Dis (2009) 199(1):108-15. doi:10.1086/595564

77. Doran KS, Liu GY, Nizet V. Group B streptococcal beta-hemolysin/cytolysin activates neutrophil signaling pathways in brain endothelium and contributes to development of meningitis. J Clin Invest (2003) 112(5):736-44. doi:10.1172/ JCI200317335

78. Liu GY, Doran KS, Lawrence T, Turkson N, Puliti M, Tissi L, et al. Sword and shield: linked group B streptococcal beta-hemolysin/cytolysin and carotenoid pigment function to subvert host phagocyte defense. Proc Natl Acad Sci U S A (2004) 101(40):14491-6. doi:10.1073/pnas.0406143101

79. Doran KS, Chang JC, Benoit VM, Eckmann L, Nizet V. Group B streptococcal beta-hemolysin/cytolysin promotes invasion of human lung epithelial cells and the release of interleukin-8. J Infect Dis (2002) 185(2):196-203. doi: $10.1086 / 338475$

80. Randis TM, Gelber SE, Hooven TA, Abellar RG, Akabas LH, Lewis EL, et al. Group B Streptococcus $\beta$-hemolysin/cytolysin breaches maternal-fetal barriers to cause preterm birth and intrauterine fetal demise in vivo. J Infect Dis (2014) 210(2):265-73. doi:10.1093/infdis/jiu067

81. Hensler ME, Liu GY, Sobczak S, Benirschke K, Nizet V, Heldt GP. Virulence role of group B Streptococcus beta-hemolysin/cytolysin in a neonatal rabbit model of early-onset pulmonary infection. J Infect Dis (2005) 191(8):1287-91. doi: $10.1086 / 428946$

82. Bebien M, Hensler ME, Davanture S, Hsu L-C, Karin M, Park JM, et al. The pore-forming toxin $\beta$ hemolysin/cytolysin triggers p38 MAPK-dependent IL10 production in macrophages and inhibits innate immunity. PLoS Pathog (2012) 8(7):e1002812. doi:10.1371/journal.ppat.1002812

83. Lang S, Palmer M. Characterization of Streptococcus agalactiae CAMP factor as a pore-forming toxin. J Biol Chem (2003) 278(40):38167-73. doi:10.1074/ jbc.M303544200

84. Jürgens D, Sterzik B, Fehrenbach FJ. Unspecific binding of group B streptococcal cocytolysin (CAMP factor) to immunoglobulins and its possible role in pathogenicity. J Exp Med (1987) 165(3):720-32. doi:10.1084/jem.165.3.720

85. Hensler ME, Quach D, Hsieh C-J, Doran KS, Nizet V. CAMP factor is not essential for systemic virulence of group B Streptococcus. Microb Pathog (2008) 44(1):84-8. doi:10.1016/j.micpath.2007.08.005

86. Podbielski A, Blankenstein O, Lütticken R. Molecular characterization of the $\mathrm{cfb}$ gene encoding group B streptococcal CAMP-factor. Med Microbiol Immunol (1994) 183(5):239-56. doi:10.1007/BF00198458

87. Chang Y-C, Olson J, Louie A, Crocker PR, Varki A, Nizet V. Role of macrophage sialoadhesin in host defense against the sialylated pathogen group B Streptococcus. J Mol Med (Berl) (2014) 92(9):951-9. doi:10.1007/s00109-0141157-y 
88. Pezzicoli A, Ruggiero P, Amerighi F, Telford JL, Soriani M. Exogenous sialic acid transport contributes to group B Streptococcus infection of mucosal surfaces. J Infect Dis (2012) 206(6):924-31. doi:10.1093/infdis/jis451

89. Chang Y-C, Olson J, Beasley FC, Tung C, Zhang J, Crocker PR, et al. Group B Streptococcus engages an inhibitory Siglec through sialic acid mimicry to blunt innate immune and inflammatory responses in vivo. PLoS Pathog (2014) 10(1):e1003846. doi:10.1371/journal.ppat.1003846

90. Bohnsack JF, Takahashi S, Hammitt L, Miller DV, Aly AA, Adderson EE. Genetic polymorphisms of group B Streptococcus scpB alter functional activity of a cellassociated peptidase that inactivates C5a. Infect Immun (2000) 68(9):5018-25. doi:10.1128/IAI.68.9.5018-5025.2000

91. Santi I, Scarselli M, Mariani M, Pezzicoli A, Masignani V, Taddei A, et al. BibA: a novel immunogenic bacterial adhesin contributing to group B Streptococcus survival in human blood. Mol Microbiol (2007) 63(3):754-67. doi:10.1111/j. 1365-2958.2006.05555.x

92. Jarva H, Hellwage J, Jokiranta TS, Lehtinen MJ, Zipfel PF, Meri S. The group B streptococcal beta and pneumococcal Hic proteins are structurally related immune evasion molecules that bind the complement inhibitor factor $\mathrm{H}$ in an analogous fashion. J Immunol (2004) 172(5):3111-8. doi:10.4049/jimmunol. 172.5 .3111

93. Jerlström PG, Chhatwal GS, Timmis KN. The IgA-binding beta antigen of the c protein complex of group B streptococci: sequence determination of its gene and detection of two binding regions. Mol Microbiol (1991) 5(4):843-9. doi:10.1111/j.1365-2958.1991.tb00757.x

94. Poyart C, Pellegrini E, Gaillot O, Boumaila C, Baptista M, Trieu-Cuot P. Contribution of Mn-cofactored superoxide dismutase (SodA) to the virulence of Streptococcus agalactiae. Infect Immun (2001) 69(8):5098-106. doi:10.1128/IAI 69.8.5098-5106.2001

95. Cornacchione P, Scaringi L, Fettucciari K, Rosati E, Sabatini R, Orefici G, et al. Group B streptococci persist inside macrophages. Immunology (1998) 93(1):86-95. doi:10.1046/j.1365-2567.1998.00402.x

96. Teixeira CF, Azevedo NL, Carvalho TM, Fuentes J, Nagao PE. Cytochemical study of Streptococcus agalactiae and macrophage interaction. Microsc Res Tech (2001) 54(4):254-9. doi:10.1002/jemt.1137

97. Poyart C, Lamy MC, Boumaila C, Fiedler F, Trieu-Cuot P. Regulation of D-alanyl-lipoteichoic acid biosynthesis in Streptococcus agalactiae involves a novel two-component regulatory system. J Bacteriol (2001) 183(21):6324-34. doi:10.1128/JB.183.21.6324-6334.2001

98. Ulrich LE, Koonin EV, Zhulin IB. One-component systems dominate signal transduction in prokaryotes. Trends Microbiol (2005) 13(2):52-6. doi:10.1016/ j.tim.2004.12.006

99. Beier D, Gross R. Regulation of bacterial virulence by two-component systems. Curr Opin Microbiol (2006) 9(2):143-52. doi:10.1016/j.mib.2006.01.005

100. Lembo A, Gurney MA, Burnside K, Banerjee A, de los Reyes M, Connelly JE et al. Regulation of CovR expression in group B Streptococcus impacts bloodbrain barrier penetration. Mol Microbiol (2010) 77(2):431-43. doi:10.1111/j. 1365-2958.2010.07215.x

101. Jiang S, Cieslewicz MJ, Kasper DL, Wessels MR. Regulation of virulence by a two-component system in group B Streptococcus. J Bacteriol (2005) 187(3):1105-13. doi:10.1128/JB.187.3.1105-1113.2005

102. Santi I, Grifantini R, Jiang S-M, Brettoni C, Grandi G, Wessels MR, et al. CsrRS regulates group B Streptococcus virulence gene expression in response to environmental pH: a new perspective on vaccine development. J Bacteriol (2009) 191(17):5387-97. doi:10.1128/JB.00370-09

103. Oliveira L, Madureira P, Andrade EB, Bouaboud A, Morello E, Ferreira P, et al. Group B Streptococcus GAPDH is released upon cell lysis, associates with bacterial surface, and induces apoptosis in murine macrophages. PLoS One (2012) 7(1):e29963. doi:10.1371/journal.pone.0029963

104. Jiang S, Park SE, Yadav P, Paoletti LC, Wessels MR. Regulation and function of pilus island 1 in group B Streptococcus. J Bacteriol (2012) 194(10):2479-90. doi:10.1128/JB.00202-12

105. Patras KA, Wang N-Y, Fletcher EM, Cavaco CK, Jimenez A, Garg M, et al. Group B Streptococcus CovR regulation modulates host immune signalling pathways to promote vaginal colonization. Cell Microbiol (2013) 15(7):1154-67. doi:10.1111/cmi.12105

106. Lamy M-C, Zouine M, Fert J, Vergassola M, Couve E, Pellegrini E, et al. CovS/CovR of group B Streptococcus: a two-component global regulatory system involved in virulence. Mol Microbiol (2004) 54(5):1250-68. doi:10.1111/j. 1365-2958.2004.04365.x
107. Rajagopal L, Vo A, Silvestroni A, Rubens CE. Regulation of cytotoxin expression by converging eukaryotic-type and two-component signalling mechanisms in Streptococcus agalactiae. Mol Microbiol (2006) 62(4):941-57. doi:10. 1111/j.1365-2958.2006.05431.x

108. Lin W-J, Walthers D, Connelly JE, Burnside K, Jewell KA, Kenney LJ, et al. Threonine phosphorylation prevents promoter DNA binding of the group B Streptococcus response regulator CovR. Mol Microbiol (2009) 71(6):1477-95. doi:10.1111/j.1365-2958.2009.06616.x

109. Firon A, Tazi A, Da Cunha V, Brinster S, Sauvage E, Dramsi S, et al. The Abi-domain protein Abxl interacts with the CovS histidine kinase to control virulence gene expression in group B Streptococcus. PLoS Pathog (2013) 9(2):e1003179. doi:10.1371/journal.ppat.1003179

110. Mancuso G, Midiri A, Beninati C, Biondo C, Galbo R, Akira S, et al. Dual role of TLR2 and myeloid differentiation factor 88 in a mouse model of invasive group B streptococcal disease. J Immunol (2004) 172:6324-9. doi:10.4049/jimmunol.172.10.6324

111. Henneke P, Dramsi S, Mancuso G, Chraibi K, Pellegrini E, Theilacker C, et al. Lipoproteins are critical TLR2 activating toxins in group B streptococcal sepsis. J Immunol (2008) 180(9):6149-58. doi:10.4049/jimmunol.180.9.6149

112. Takeda K, Takeuchi O, Akira S. Recognition of lipopeptides by toll-like receptors. J Endotoxin Res (2002) 8(6):459-63. doi:10.1177/ 09680519020080060101

113. Motoi Y, Shibata T, Takahashi K, Kanno A, Murakami Y, Li X, et al. Lipopeptides are signaled by toll-like receptor 1, 2 and 6 in endolysosomes. Int Immunol (2014) 26(10):563-73. doi:10.1093/intimm/dxu054

114. Charrel-Dennis M, Latz E, Halmen KA, Trieu-Cuot P, Fitzgerald KA, Kasper DL, et al. TLR-independent type I interferon induction in response to an extracellular bacterial pathogen via intracellular recognition of its DNA. Cell Host Microbe (2008) 4(6):543-54. doi:10.1016/j.chom.2008.11.002

115. Deshmukh SD, Müller S, Hese K, Rauch KS, Wennekamp J, Takeuchi O, et al. NO is a macrophage autonomous modifier of the cytokine response to streptococcal single-stranded RNA. J Immunol (2012) 188(2):774-80. doi:10.4049/jimmunol.1101383

116. Deshmukh SD, Kremer B, Freudenberg M, Bauer S, Golenbock DT, Henneke P. Macrophages recognize streptococci through bacterial single-stranded RNA. EMBO Rep (2011) 12(1):71-6. doi:10.1038/embor.2010.189

117. Mancuso G, Gambuzza M, Midiri A, Biondo C, Papasergi S, Akira S, et al. Bacterial recognition by TLR7 in the lysosomes of conventional dendritic cells. Nat Immunol (2009) 10(6):587-94. doi:10.1038/ni.1733

118. Gupta R, Ghosh S, Monks B, Deoliveira R, Tzeng T, Kalantari P, et al. RNA and $\beta$-hemolysin of group B Streptococcus induce IL-1 $\beta$ by activating NLRP3 inflammasomes in mouse macrophages. J Biol Chem (2014) 289(20):13701-5. doi:10.1074/jbc.C114.548982

119. Costa A, Gupta R, Signorino G, Malara A, Cardile F, Biondo C, et al. Activation of the NLRP3 inflammasome by group B streptococci. J Immunol (2012) 188(4):1953-60. doi:10.4049/jimmunol.1102543

120. Jöckel S, Nees G, Sommer R, Zhao Y, Cherkasov D, Hori H, et al. The $2^{\prime}$ O-methylation status of a single guanosine controls transfer RNA-mediated toll-like receptor 7 activation or inhibition. J Exp Med (2012) 209(2):235-41. doi:10.1084/jem.20111075

121. Hochrein H, Kirschning CJ. Bacteria evade immune recognition via TLR13 and binding of their 23S rRNA by MLS antibiotics by the same mechanisms Oncoimmunology (2013) 2(3):e23141. doi:10.4161/onci.23141

122. Madureira P, Andrade EB, Gama B, Oliveira L, Moreira S, Correia-Neves M, et al. Inhibition of IL-10 production by maternal antibodies against group B Streptococcus GAPDH confers immunity to offspring by favoring neutrophil recruitment. PLoS Pathog (2011) 7(11):e1002363. doi:10.1371/journal.ppat. 1002363

123. Seifert KN, McArthur WP, Bleiweis AS, Brady LJ. Characterization of group B streptococcal glyceraldehyde-3-phosphate dehydrogenase: surface localization, enzymatic activity, and protein-protein interactions. Can J Microbiol (2003) 49(5):350-6. doi:10.1139/w03-042

124. Kim J-W, Dang CV. Multifaceted roles of glycolytic enzymes. Trends Biochem Sci (2005) 30(3):142-50. doi:10.1016/j.tibs.2005.01.005

125. Pancholi V, Fischetti VA. A major surface protein on group A streptococci is a glyceraldehyde-3-phosphate-dehydrogenase with multiple binding activity. J Exp Med (1992) 176(2):415-26. doi:10.1084/jem.176.2.415

126. Bergmann S, Rohde M, Hammerschmidt S. Glyceraldehyde-3-phosphate dehydrogenase of Streptococcus pneumoniae is a surface-displayed plasminogen- 
binding protein. Infect Immun (2004) 72(4):2416-9. doi:10.1128/IAI.72.4. 2416-2419.2004

127. Ling E, Feldman G, Portnoi M, Dagan R, Overweg K, Mulholland F, et al. Glycolytic enzymes associated with the cell surface of Streptococcus pneumoniae are antigenic in humans and elicit protective immune responses in the mouse. Clin Exp Immunol (2004) 138(2):290-8. doi:10.1111/j.1365-2249.2004.02628.x

128. Fluegge K, Schweier O, Schiltz E, Batsford S, Berner R. Identification and immunoreactivity of proteins released from Streptococcus agalactiae. Eur J Clin Microbiol Infect Dis (2004) 23(11):818-24. doi:10.1007/s10096-004-1229-y

129. Alvarez RA, Blaylock MW, Baseman JB. Surface localized glyceraldehyde-3phosphate dehydrogenase of Mycoplasma genitalium binds mucin. Mol Microbiol (2003) 48(5):1417-25. doi:10.1046/j.1365-2958.2003.03518.x

130. Madureira P, Baptista M, Vieira M, Magalhaes V, Camelo A, Oliveira L, et al. Streptococcus agalactiae GAPDH is a virulence-associated immunomodulatory protein. J Immunol (2007) 178(3):1379-87. doi:10.4049/jimmunol.178.3.1379

131. Andrade EB, Alves J, Madureira P, Oliveira L, Ribeiro A, Cordeiro-daSilva A, et al. TLR2-induced IL-10 production impairs neutrophil recruitment to infected tissues during neonatal bacterial sepsis. J Immunol (2013) 191(9):4759-68. doi:10.4049/jimmunol.1301752

132. Kamanaka M, Kim ST, Wan YY, Sutterwala FS, Lara-Tejero M, Galán JE, et al. Expression of interleukin-10 in intestinal lymphocytes detected by an interleukin-10 reporter knockin tiger mouse. Immunity (2006) 25(6):941-52. doi:10.1016/j.immuni.2006.09.013

133. Gérard C, Bruyns C, Marchant A, Abramowicz D, Vandenabeele P, Delvaux $\mathrm{A}$, et al. Interleukin 10 reduces the release of tumor necrosis factor and prevents lethality in experimental endotoxemia. J Exp Med (1993) 177(2):547-50. doi:10.1084/jem.177.2.547

134. Cusumano V, Genovese F, Mancuso G, Carbone M, Fera MT, Teti G. Interleukin-10 protects neonatal mice from lethal group B streptococcal infection. Infect Immun (1996) 64(7):2850-2.

135. Smith SR, Terminelli C, Kenworthy-Bott L, Calzetta A, Donkin J. The cooperative effects of TNF-alpha and IFN-gamma are determining factors in the ability of IL-10 to protect mice from lethal endotoxemia. J Leukoc Biol (1994) 55(6):711-8.

136. Howard M, Muchamuel T, Andrade S, Menon S. Interleukin 10 protects mice from lethal endotoxemia. J Exp Med (1993) 177(4):1205-8. doi:10.1084/jem. 177.4.1205

137. Sing A, Rost D, Tvardovskaia N, Roggenkamp A, Wiedemann A, Kirschning CJ, et al. Yersinia V-antigen exploits toll-like receptor 2 and CD14 for interleukin 10-mediated immunosuppression. J Exp Med (2002) 196(8):1017-24. doi:10.1084/jem. 20020908

138. Jang S, Uematsu S, Akira S, Salgame P. IL-6 and IL-10 induction from dendritic cells in response to Mycobacterium tuberculosis is predominantly dependent on TLR2-mediated recognition. J Immunol (2004) 173(5):3392-7. doi:10.4049/jimmunol.173.5.3392

139. Dillon S, Agrawal A, Van Dyke T, Landreth G, McCauley L, Koh A, et al. A tolllike receptor 2 ligand stimulates Th2 responses in vivo, via induction of extracellular signal-regulated kinase mitogen-activated protein kinase and c-Fos in dendritic cells. J Immunol (2004) 172(8):4733-43. doi:10.4049/jimmunol.172. 8.4733

140. Kenzel S, Mancuso G, Malley R, Teti G, Golenbock DT, Henneke P. c-Jun kinase is a critical signaling molecule in a neonatal model of group B streptococcal sepsis. J Immunol (2006) 176:3181-8. doi:10.4049/jimmunol.176.5.3181

141. Moore KW, De Waal Malefyt R, Coffman RL, O'Garra A. Interleukin-10 and the interleukin-10 receptor. Annu Rev Immunol (2001) 19:683-765. doi:10.1146/annurev.immunol.19.1.683

142. Couper KN, Blount DG, Riley EM. IL-10: the master regulator of immunity to infection. J Immunol (2008) 180(9):5771-7. doi:10.4049/jimmunol.180.9.5771

143. Smythies LE, Maheshwari A, Clements R, Eckhoff D, Novak L, Vu HL, et al. Mucosal IL-8 and TGF- $\beta$ recruit blood monocytes: evidence for cross-talk between the lamina propria stroma and myeloid cells. J Leukoc Biol (2006) 80(September):492-9. doi:10.1189/jlb.1005566

144. Varol C, Zigmond E, Jung S. Securing the immune tightrope: mononuclear phagocytes in the intestinal lamina propria. Nat Rev Immunol (2010) 10(6):415-26. doi:10.1038/nri2778

145. Smythies LE, Shen R, Bimczok D, Novak L, Clements RH, Eckhoff DE, et al. Inflammation anergy in human intestinal macrophages is due to Smad-induced IkappaBalpha expression and NF-kappaB inactivation. J Biol Chem (2010) 285(25):19593-604. doi:10.1074/jbc.M109.069955
146. Maheshwari A, Kelly DR, Nicola T, Jain SK, Murphy-Ullrich J, Athar M, et al. TGF- $\beta 2$ suppresses macrophage cytokine production and mucosal inflammatory responses in the developing intestine. Gastroenterology (2012) 140(1):242-53. doi:10.1053/j.gastro.2010.09.043

147. Begue B, Verdier J, Rieux-Laucat F, Goulet O, Morali A, Canioni D, et al. Defective IL10 signaling defining a subgroup of patients with inflammatory bowel disease. Am J Gastroenterol (2011) 106(8):1544-55. doi:10.1038/ajg.2011.112

148. Gertz EM, Ph D, Schäffer AA, Noyan F, Perro M, Sc M, et al. Inflammatory bowel disease and mutations affecting the interleukin-10 receptor. NEnglJMed (2009) 361(21):2033-45. doi:10.1056/NEJMoa0907206

149. Glocker E, Frede N, Perro M, Sebire N, Elawad M, Shah N, et al. Case report infant colitis - it's in the genes. Lancet (2010) 376:1272. doi:10.1016/S01406736(10)61008-2

150. Reindl W, Weiss S, Lehr H-A, Förster I. Essential crosstalk between myeloid and lymphoid cells for development of chronic colitis in myeloid-specific signal transducer and activator of transcription 3-deficient mice. Immunology (2007) 120(1):19-27. doi:10.1111/j.1365-2567.2006.02473.x

151. Hoshi N, Schenten D, Nish SA, Walther Z, Gagliani N, Flavell RA, et al. MyD88 signalling in colonic mononuclear phagocytes drives colitis in IL-10-deficient mice. Nat Commun (2012) 3:1120. doi:10.1038/ncomms2113

152. Krause JC, Ghandil P, Chrabieh M, Casanova J, Picard C, Puel A. Very lateonset group B Streptococcus meningitis, sepsis, and systemic shigellosis due to interleukin-1 receptor-associated kinase-4 deficiency. Clin Infect Dis (2009) 49:1393-6. doi:10.1086/630206

153. Picard C, von Bernuth H, Ghandil P, Chrabieh M, Levy O, Arkwright PD, et al. Clinical features and outcome of patients with IRAK-4 and MyD88 deficiency. Medicine (Baltimore) (2010) 89(6):403-25. doi:10.1097/ MD.0b013e3181fd8ec3

154. Picard C, Casanova J, Puel A. Infectious diseases in patients with IRAK-4, MyD88, NEMO, or IкB $\alpha$ deficiency. Clin Microbiol Rev (2011) 24(3):490-7. doi:10.1128/CMR.00001-11

155. Berner R, Welter P, Brandis M. Cytokine expression of cord and adult blood mononuclear cells in response to Streptococcus agalactiae. Pediatr Res (2002) 51:304-9. doi:10.1203/00006450-200203000-00007

156. Levy O, Jean-Jacques RM, Cywes C, Sisson RB, Zarember KA, Godowski PJ, et al. Critical role of the complement system in group B Streptococcus-induced tumor necrosis factor alpha release. Infect Immun (2003) 71(11):6344-53. doi:10.1128/IAI.71.11.6344-6353.2003

157. Williams PA, Bohnsack JF, Augustine NH, Drummond WK, Rubens CE, Hill HR. Production of tumor necrosis factor by human cells in vitro and in vivo, induced by group B streptococci. J Pediatr (1993) 123(2):292-300. doi:10.1016/S0022-3476(05)81706-8

158. Kenzel S, Mergen M, von Süßkind-Schwendi J, Wennekamp J, Deshmukh $\mathrm{SD}$, Haeffner $\mathrm{M}$, et al. Insulin modulates the inflammatory granulocyte response to streptococci via phosphatidylinositol 3-kinase. J Immunol (2012) 189(9):4582-91. doi:10.4049/jimmunol.1200205

159. Wennekamp J, Henneke P. Induction and termination of inflammatory signaling in group B streptococcal sepsis. Immunol Rev (2008) 225:114-27. doi:10.1111/j.1600-065X.2008.00673.x

160. Pong A, Bradley JS. Bacterial meningitis and the newborn infant. Infect Dis Clin North Am (1999) 13(3):711-33, viii. doi:10.1016/S0891-5520(05)70102-1

161. Filias A, Theodorou GL, Mouzopoulou S, Varvarigou AA, Mantagos S, Karakantza M. Phagocytic ability of neutrophils and monocytes in neonates. BMC Pediatr (2011) 11:29. doi:10.1186/1471-2431-11-29

162. Harris MC, Shalit M, Southwick FS. Diminished actin polymerization by neutrophils from newborn infants. Pediatr Res (1993) 33(1):27-31. doi:10.1203/ 00006450-199301000-00006

163. Sacchi F, Augustine NH, Coello MM, Morris EZ, Hill HR. Abnormality in actin polymerization associated with defective chemotaxis in neutrophils from neonates. Int Arch Allergy Appl Immunol (1987) 84(1):32-9. doi:10.1159/ 000234395

164. Drossou V, Kanakoudi F, Diamanti E, Tzimouli V, Konstantinidis T, Germenis A, et al. Concentrations of main serum opsonins in early infancy. Arch Dis Child Fetal Neonatal Ed (1995) 72(3):F172-5. doi:10.1136/fn.72.3.F172

165. Abughali N, Berger M, Tosi MF. Deficient total cell content of CR3 (CD11b) in neonatal neutrophils. Blood (1994) 83(4):1086-92.

166. Nupponen I, Pesonen E, Andersson S, Mäkelä A, Turunen R, Kautiainen H, et al. Neutrophil activation in preterm infants who have respiratory distress syndrome. Pediatrics (2002) 110(1 Pt 1):36-41. doi:10.1542/peds.110.1.36 
167. Källman J, Schollin J, Schalèn C, Erlandsson A, Kihlström E. Impaired phagocytosis and opsonisation towards group B streptococci in preterm neonates. Arch Dis Child Fetal Neonatal Ed (1998) 78(1):F46-50. doi:10.1136/fn.78.1.F46

168. Ballinger MN, Peters-Golden M, Moore BB. Impaired neonatal macrophage phagocytosis is not explained by overproduction of prostaglandin E2. Respir Res (2011) 12(1):155. doi:10.1186/1465-9921-12-155

169. Rose S, Lichtenheld M, Foote MR, Adkins B. Murine neonatal CD4+ cells are poised for rapid Th2 effector-like function. J Immunol (2007) 178(5):2667-78. doi:10.4049/jimmunol.178.5.2667

170. Zaghouani H, Hoeman CM, Adkins B. Neonatal immunity: faulty T-helpers and the shortcomings of dendritic cells. Trends Immunol (2009) 30(12):585-91. doi:10.1016/j.it.2009.09.002

171. Netea MG, Quintin J, van der Meer JW. Trained immunity: a memory for innate host defense. Cell Host Microbe (2011) 9(5):355-61. doi:10.1016/j.chom.2011. 04.006

172. Aksoy E, Albarani V, Nguyen M, Laes J-F, Ruelle J-L, De Wit D, et al. Interferon regulatory factor 3-dependent responses to lipopolysaccharide are selectively blunted in cord blood cells. Blood (2007) 109(7):2887-93. doi:10.1182/blood2006-06-027862

173. De Wit D, Tonon S, Olislagers V, Goriely S, Boutriaux M, Goldman M, et al. Impaired responses to toll-like receptor 4 and toll-like receptor 3 ligands in human cord blood. JAutoimmun (2003) 21(3):277-81. doi:10.1016/j.jaut.2003. 08.003

174. Zhang X, Deriaud E, Jiao X, Braun D, Leclerc C, Lo-Man R. Type I interferons protect neonates from acute inflammation through interleukin 10-producing B cells. J Exp Med (2007) 204(5):1107-18. doi:10.1084/jem.20062013

175. Chelvarajan RL, Collins SM, Doubinskaia IE, Goes S, Van Willigen J, Flanagan D, et al. Defective macrophage function in neonates and its impact on unresponsiveness of neonates to polysaccharide antigens. J Leukoc Biol (2004) 75(6):982-94. doi:10.1189/jlb.0403179

176. Genovese F, Mancuso G, Cuzzola M, Biondo C, Beninati C, Delfino D, et al. Role of IL-10 in a neonatal mouse listeriosis model. J Immunol (1999) 163(5):2777-82.
177. Sun C-M, Deriaud E, Leclerc C, Lo-Man R. Upon TLR9 signaling, CD5+ B cells control the IL-12-dependent Th1-priming capacity of neonatal DCs. Immunity (2005) 22(4):467-77. doi:10.1016/j.immuni.2005.02.008

178. Kollmann TR, Crabtree J, Rein-Weston A, Blimkie D, Thommai F, Wang XY, et al. Neonatal innate TLR-mediated responses are distinct from those of adults. J Immunol (2009) 183(11):7150-60. doi:10.4049/jimmunol.0901481

179. Wynn JL, Cvijanovich NZ, Allen GL, Thomas NJ, Freishtat RJ, Anas N, et al. The influence of developmental age on the early transcriptomic response of children with septic shock. Mol Med (2011) 17(11-12):1146-56. doi:10.2119/ molmed.2011.00169

180. Belderbos ME, van Bleek GM, Levy O, Blanken MO, Houben ML, Schuijff $\mathrm{L}$, et al. Skewed pattern of toll-like receptor 4-mediated cytokine production in human neonatal blood: low LPS-induced IL-12p70 and high IL-10 persist throughout the first month of life. Clin Immunol (2009) 133(2):228-37. doi:10.1016/j.clim.2009.07.003

Conflict of Interest Statement: The authors declare that the research was conducted in the absence of any commercial or financial relationships that could be construed as a potential conflict of interest.

Received: 30 June 2014; accepted: 05 October 2014; published online: 29 October 2014. Citation: Landwehr-Kenzel $S$ and Henneke $P$ (2014) Interaction of Streptococcus agalactiae and cellular innate immunity in colonization and disease. Front. Immunol. 5:519. doi: 10.3389/fimmu.2014.00519

This article was submitted to Immunotherapies and Vaccines, a section of the journal Frontiers in Immunology.

Copyright (c) 2014 Landwehr-Kenzel and Henneke. This is an open-access article distributed under the terms of the Creative Commons Attribution License (CC BY). The use, distribution or reproduction in other forums is permitted, provided the original author(s) or licensor are credited and that the original publication in this journal is cited, in accordance with accepted academic practice. No use, distribution or reproduction is permitted which does not comply with these terms. 